\title{
MEASURING THE DIRECTION OF CAUSALITY BETWEEN FOREIGN EXCHANGE PARALLEL PREMIUM AND BA LANCE OF PAYMENTPOSITION. NIGERIAEVIDENCE,1981-2019.
}

${ }^{1}$ EZEMA, Clifford Anene. Ph.D, ${ }^{2}$ OVUTE, Francis Echezona Ph.D and ${ }^{3} \mathrm{OBINABO}$, Chinyere Rose Ph.D

${ }^{1}$ Department of Insurance and Risk Management, Faculty of Management Sciences, Enugu State University of Science and Technology, (ESUT), Enugu.

${ }^{2 \& 3}$ Department of Accountancy, Faulty of management sciences, Ebonyi State University, Abakaliki

\begin{abstract}
The objective of the study was to measure the causal relationship existing between foreign exchange Parallel Premium and balance of payment position in Nigeria using grander causality methodology for analysis. The analyses from the pair wise granger causality result reveals that Foreign Exchange Parallel Premium and Balance of payment in Nigeria have a unidirectional relationship On the basis of the above findings, the study concludes that foreign exchange Parallel Premium has been seen to have a serious unidirectional influences to Macroeconomic standings and financial system operation in Nigeria.It was recommended that the nexus between Foreign Exchange Parallel Premium and balance of payment series needs to be effectively managed by eliminating black market activities in exchange rates. This Strategy will boast the economy given the fact that the economic standing of any nation can be enhanced by effective management of exchange rate volatility and black market problems.
\end{abstract}

ABSTRACT

KEYWORDS:Foreign Exchange Parallel Premium, balance of payment,exchange rate

\section{INTRODUCTION}

In developing continent like Africa, foreign exchange parallel premium has been one of the major problems facing their Macro economic performance(Attah-Obeng,Enu,Osei,Gymialla \& Opaku ,2013). Exchange rate gap and its associated problems have been evaluated in various continents. All seem to emphasize that Parallel premium has created a negative response to some of their macroeconomic aggregates in their countries while some of the studies insisted that foreign exchange parallel premium has positive responses to some macroeconomic aggregates. Hence, there have not been conclusive arguments on the positive or negative attributes to the economy and on how to eliminate these foreign exchange rate premiums. In Nigeria, the same premium continues to surface every year despite all efforts aimed at eliminating it. These resistances seem to trigger the research interest.

However, efforts have been made in the country to reduce these foreign exchange parallel premium but these efforts remain inactive. This is because government intervention in exchange rate market leads to emergence of parallel or black market for foreign exchange. It has also been acknowledged that foreign exchange parallel premium has a negative response on the macroeconomic aggregates such as the gross domestic product, balance of payment and external reserve, since parallel premium indicates a market distortion, reduces trade and growth, it has been deduced that the spread between the foreign exchange parallel market 
and real effective exchange rate may enforce the speculative activities in foreign currencies and illegal trade, and result in capital flight and deviation of remittances flows from the formal channels to informal channels.

Throughout the last few decades, the issue of foreign exchange parallel premium has raised a considerable policy attention in developing and underdeveloped countries. This is because a huge gap between parallel and official exchange rate has lead to devastating responses on macroeconomic aggregates in terms of negative economic growth, deficit balance of payment, dwindling external reserve, unattractive investment environment, decimal exports performance, low manufacturing capacity utilization, high level of inflation, heavy external debt burden, high unemployment rate, high level of income inequality, poverty, to mention a few.

The study of the causal relationship existing between foreign exchange parallel premium and balance of payment position in Nigeria has been scarcely done in Nigerian in the past. Some of the study carried out on exchange rate in Nigeria was on exchange rate volatility, variability, impact, relationship and fluctuations to Economic Growth. None of the study was able to carry out a study on the causality of foreign exchange parallel premium to balance of payment position in Nigeria. Hence, this study sought to investigate the causality of foreign exchange parallel premium to balance of payment position in Nigeria resulting to a research gap which the study wants to fill.

\section{CHAPTER TWO: REVIEW OF RELATED LITERATURE Conceptual Review \\ Concept of Foreign Exchange Market}

Orji (2001) sees foreign exchange market as an arrangement which existed to assists buyers and seller of foreign currency to enter into contact of buying and selling of foreign currency. He further stressed that unlike other markets where local currencies are exchanged; foreign exchange market involves money exchanged for money, one currency exchanged for another currency. The bases of this market are to bring international settlement to the investor's door step.

Oleka (2009) defines Nigerian foreign exchange market as a market that is made up of three district segment, the official, autonomous consisting the interbank and bureau de change as well as parallel market operators called black market. The markets are discussed under the following concept.

\section{Foreign Exchange Parallel Market (black Market):}

Ismaila (2016) defines foreign exchange parallel market as a black market of foreign exchange where the price of the foreign exchange is sold at the illegal means. The parallel market for foreign exchange has been in existence from the first world war of 1945 to exchange control era of 1962 via the trade Liberalization era of 1986 till the current era of Consolidation. The disparity in exchange rate was even greater than the official rate and the widening gap in the exchange rate has further strengthened the existence of the parallel market business. Therefore, CBN (2014) sees parallel market as a residual market as it accommodates spillover demand of foreign exchange from other sources. It has been established that scarcity in official sources and the CBN regulatory tendencies to reduce this rate directly encouraged the growth and development of parallel markets.(Odogun,1975)

\subsubsection{Foreign exchange parallel Premium. (FEPP)}

Okeafor (2014) economically defines foreign exchange parallel premium as the amount by which the parallel exchange rate exceeds the official exchange rate. This can be expressed 
using variable thus: $Z x=\quad \underline{P x}-Q x W h e r e ~ Z x=$ Parallel Premium, $P x=$ Parallel Exchange Rate/black market Exchange Rate, Qx = Official Exchange Rate

Nkurnzinza (2002) defines the black market in foreign exchange as the underground, parallel, group, street, and unofficial, curb, fragmented or informal market. Dorduno (1994) opines that development of parallel market for foreign exchange with high premium indicates a basic disequilibrium both in the foreign exchange market and trade regimes and as a result involves substantial social and economic cost. The growth of foreign exchange parallel market causes the government to lose control over foreign exchange as more and more of the official transactions are diverted to the parallel market. At the same time, black market premium for foreign exchange function as an implicit tax on export thereby serving as a disincentive to export production and a sources of hidden fiscal treasure and revenue (Pinto, 1988).

\section{Concept of Balance of Payment}

Balance of payment is a concept where importation is used to balance with exportation. The exchange rate of foreign currencies is dependent on the country's balance of payment position. A favorable balance of payment raises the exchange rate in the capital account while an unfavorable balance of payment reduces the exchange rate. Thus, this concept implies that exchange rate is determined by the demand and supply of foreign exchange which was sourced through balance of payment, external reserve, payment of external debt etc.

\section{Concept of Importation}

Amaedo (2017) defines imports as foreign goods and services bought by residents of a country. Resident of a country includes citizens, businesses and the government. It does not matter what the imports are or how they are sent, they can be shipped, sent by e-mail or even plane. If they are produced in a foreign country and sold to domestic residents, they are called imports.

\section{Concept of Exportation}

Mohamed (2008) sees exportation as function of international trade whereby goods produced in one country are shipped to another country for future use, sale, or trade. The sales of such goods add to the nations GDP. The process of sales of goods where the goods moves from one based country of residence to oversee and are sold to finance import is called exportation.

\section{CHAPTER THREE: THEORITICAL FRAMEWORK}

Parallel foreign exchange rate theories have been a very serious issue in exchange rate determination among scholars and countries. This is because exchange rate problems consists of one important macro-economic problem facing every developing nation. Dornbusch (1989) identifies one major theory of exchange rate

\section{Balanced Portfolio Theory Of Exchange Rate:}

This is an exchange rate theory propounded by Mundell Fischer in 1968 called the balance of payment theory of exchange rate. Hence, the exchange rate of foreign currencies is dependent on the assumption of the country's balance of payment position. A favorable balance of payment raises the exchange rate in the capital account while an unfavorable balance of payment reduces the exchange rate. Thus, the theory implies that exchange rate is determined by the demand and supply of foreign exchange (Jhingan,2010)

$\mathrm{Yu}$-hsing (2006) expresses that the demand for foreign currency is more than its supply. This caused the eternal value of the domestic currency to fall in relation to the foreign currency. Consequently, the exchange rate falls. On the other hand, in case the balance of payment is 
favorable, the demand for foreign currency is less than its supply at any given exchange rate. This cause the external value of the domestic currency to raise in relation to the foreign currency, consequently, the exchange rate also rises.

\section{Empirical Review}

Ebaidalla (2017) examined the impact of Foreign exchange parallel premium to macro economic performance in Sudan using vector auto regressive model. Results reveal that Foreign exchange parallel premium positively and significantly affected by policy variable such as real and effective exchange rate, trade openness and money supply but negatively and significant affect GDP, expected rate of devaluation and foreign aid. The study concluded that narrowing official and black market exchange rate will contain inflationary pressure, improve the economic performance of Sudan with more emphases on boasting the economic growth.

Ismaila (2016) examined the long run impact exchange rate depreciation to Nigerian economic growth during the SAP and post SAP period (1986 - 2012) using Johansson cointegration test. Result shows that exchange rate depreciation has a positive and significant impact on broad money supply; net export and total government expenditure in the long run while exchange rate depreciation has direct negative and non-significant response to Nigerian economy in both short and long run. This implies that exchange rate depreciation during SAP has robust effect on GDP and advised that policy makers should not only rely on exchange rate depreciation but use policy instrument to induce economic growth. Also, the study should use it to compliment other macro-economic variables such as monetary and fiscal policies.

Ayodele and Obafemi (2015) examined the fiscal and quasi fiscal effect of the Foreign exchange parallel premium to Nigeria GDP using OLS regression. Result reveals that the politics of Foreign exchange parallel premium and its behavior causes a negative and significant shock on GDP. The study concluded that unification of real and effective exchange rate with black market exchange rate will prevent necessitation, depreciation and instability in the economic system.

Hung (2015) investigated the impact of Foreign exchange parallel premium to the economy of Vietnam using two ways least square regression technique. Econometric analysis shows that Foreign exchange parallel premium parallel negatively affect the GDP both in the short and long run but positively impact on broad money Supply and official exchange rate. Hence, an increase in money supply by $1 \%$ causes exchange rate in the parallel market to be depreciated by $0.015 \%$ meaning that 1 percent devaluation of the official exchange rate would bring about 1.33 percent devaluation of the parallel market rates. The study recommended that if the Foreign exchange parallel premium continues to increase with control, it will destroy the economy of Vietnam irrespective of the level of Foreign exchange parallel premium management.

Ebiadalla and Abidalla (2014) studied the impact of Foreign exchange parallel premium to macroeconomic variable in Sudan using Auto regressive distributed lag model. Result reveals that Foreign exchange parallel premium in Sudan negatively and significantly impact on the flow of migrants' remittance and as well the GDP in Sudan .It was also founded that Foreign exchange parallel premium positively improves foreign aids, encourage trade openness and influences real effective exchange rate. It was recommended that monetary authorities should eliminate foreign exchange black market by equating the demand of foreign exchange with the supply at any given period.

Ngerebo-aandibe (2013) empirically investigated the causal relationship between exchange rate, balance of payment, external debt, external reserves, gross domestic product growth rate and inflation rate in Nigeria post Structural Adjustment Programme (SAP), for the period of 
1987-2011. The authors employed the Johansen cointegration test, equation estimation and Granger causality tests approach considering the ADF and PP unit root tests. The Johansen cointegration result revealed that there exists a long-run equilibrium relationship among the indicators; while the Granger causality test between the dependent and independent variables showed a unidirectional causality running from exchange rate to BOP, external reserves and gross domestic product growth rate in Nigeria. Also, the result showed a unidirectional causality running from gross domestic product growth rate to external reserve in Nigeria. Umoru and Odjegba(2013) analyzed the relationship between exchange rate misalignment and balance of payments (BOP) mal-adjustment in Nigeria for the period of 1973 through to 2012. Analytical tools used were the vector error correction econometric modeling (VECM) technique and pairwise Granger causality test. Findings provided that Nigerian's balance of payments position interacts positively with exchange rate in Nigeria. The result also showed a unidirectional causality running from exchange rate misalignment to balance of payments adjustment in Nigeria at the $1 \%$ level.

Ayodeji and Sasheed (2012) examine the impact of exchange rate to economic growth in Nigeria using the traditional ordinary least square regression. Finding indicated that exchange rate has a negative and statistically significant impact on GDP. The study concluded that effort should be directed on how to check the menace of exchange rate and capital flight in Nigeria and also the need in training the Nigerian custom in tackling cases of Over-invoicing and under-invoicing in import and exports.

Ibrahim (2011) investigated the impact of change in external reserve positions of Nigeria on domestic investment, inflation and exchange rates. Using a combination of Ordinary Least Square (OLS) and Vector Error Correction (VEC) methods, the study provided that changes in external reserves in the country only influences Foreign Direct Investment (FDI) and exchange rates and has no influence on domestic investment and inflation rates. The study therefore suggested that there is the need for broader reserve management strategies that will aim at maximizing the gains from oil export revenue by utilizing more of these resources to boost domestic investment.

Olayungbo andAkinbobbola (2011) carried out an empirical investigation on the relationship between foreign exchange reserves and exchange rates (nominal and real) in Nigeria. The study used a quarterly time series data for the period of 1970:Q1 to 2006:Q4 and employed the Quandt-Andrew break point test, unit root test, cointegration test, Granger causality test, ECM mechanism. The findings revealed both short run and long run relationship between foreign reserve and nominal exchange rate in Nigeria. The study also found a unidirectional causality running from nominal exchange rate to foreign exchange reserve without a feedback.

Kazeromi and Feshari (2010) studied the impact of real exchange rate volatility, on non-oil exports of Iran using the period of 1971 - 2007. The study used GARCH Model and discovered that exchange rate and its volatility has a negative long run effect to non-oil exports in Iran.

Imoisi, Uzomba and Olatinji (2010) carried out an analysis of interest and exchange rate effect on the Nigeria economy from 1975 - 2008 using ordinary least square and cointegration analysis. Results establish the existence of a long run relationship between the variables of interest. Result shows that increase in interest rate shows a negative returned to investment and subsequently to economic growth. Hence interest rate and exchange rate variability creates a negative effect on the Nigeria economy. The study concluded that interest rate and exchange rate should be property managed so as to stem interest growth driven through investment.

Abounoori and Zoberri (2010) investigated the impact of Foreign exchange parallel premium to the economic growth of Iran. They estimated long run relationship between Foreign 
exchange parallel premium and economic growth of Iran using Johannes co integration approach. Result reveals that real exchange rate gap called premium has a negative and non significant impact on Iranish GDP, positive impact to broad money supply, Private sector credit and exportation all in the short run and a long run negative and a contradictory impact on the economy of Iran.

Makochekenwa (2010) examined the impact of Foreign exchange parallel premium to economic growth in Zimbabwe using stock flow OLS regression model from 1979 -2006.

Result reveals that Foreign exchange parallel premium have a positive and significant impact to international reserve, lag value of the black market premium, expected rate of devaluation, and broad money supply but a negative impacts on economic growth and inflation in Zimbabwe. The study concludes that the government will use monetary policies to reduce the level of expansion in premium by using exchange risk management practice of unifying both real effective exchange rates with parallel market rate.

\section{METHODOLOGY}

\section{Research design}

This study adopted the expost-facto research design. The expost-facto research design is described as after-the-fact research (Onwumere, 2009). This is suitable for the work given that it is based on an already completed event and the researcher is meant to analyses the outcomes of the already completed event and draw reasonable conclusions

\section{Model Specification}

This study adopted a model used by Ebiadalla and Abidalla (2014). The model used by Ebiadalla and Abidalla (2014)was the Auto regressive Distributed lag model. (ARDL).The model for thiswork is a special Classical multiple Regression Model called Auto regressive Distributed lag model. (ARDL). According to Ebiadalla and Abidalla (2014) Model=GDP = $f(F E P P)$ but this study used granger causality

Pair wise Granger Causality: This will be tested using the Pair wise Granger Causality Test following the form developed by Granger (1981), the Granger Causality model equation is stated thus:

$$
\mathrm{x}_{\mathrm{t}}=\sum_{\substack{i=1 j=1 \\ \alpha_{1} \mathrm{y}_{\mathrm{t}-1}+\sum \beta_{1} \mu_{\mathrm{t}-1}+\varepsilon_{\mathrm{t}}}}^{m n}
$$

Where $\mathrm{X}=$ caused variable (Foreign exchange parallel premium) LNFEPP

$\mathrm{Y}=$ Causal variables, $\mathrm{BOP}$. .

There is no causality between the FEPP and bop in Nigeria.

$y t=\sum_{i=j}^{m} X_{1} y_{t-1}+\sum_{j=1}^{n} \beta_{1} \mu_{t-1}+\varepsilon_{t}$

$\mathrm{y}=$ the variable whose causation is being appraised, $y_{t-1}=$ lagged values of the variable.

The result of the test will show unidirectional, bidirectional or no causality among the variables under study.

\section{Technique of Data Analysis}

\section{GRANGER CAUSALITY MODEL}

Granger causality model was used to know if there is causality or no causality. If there is causality, is it unidirectional or bidirectional causality. 


\section{CHAPTER FOUR: DATA PRESENTATION AND ANALYSES}

\subsection{Data Presentation}

TABLE 4.1. FORIEGN EXCHANGE PARLELL PREMIUM AND MACRO ECONOMIC AGGREGATES OF NIGERIA, 1981-2016.

From the table below, it contains Foreign Exchange parallel premium and selected macroeconomic Performance indicators such as Gross Domestic Product, External Reserve and Balance of Payment collected from the central bank of Nigeria statistical bulletin covering the period of 1981-2016.The data is a set of annualized time series required for empirical analysis as adopted from the model which was specified in chapter three. The variable of FEPP, GDP and EXTRSV are log transformed to bring down the data size and ensure linearity, and BOP was also log transformed to be consistent with unit root diagnostic test.

$\begin{array}{rcccr}\text { YEAR } & \text { LNFEPP } & \text { LNGDP } & \text { LNBOP } & \text { LNEXTRSV } \\ 1981 & 0.105364 & 4.546799 & 7.123333 & 7.800409 \\ 1982 & 0.019803 & 4.615226 & 6.780998 & 6.950144 \\ 1983 & 0.582216 & 4.701026 & 7.088776 & 5.413434 \\ 1984 & 1.252763 & 4.755915 & 8.446067 & 6.565406 \\ 1985 & 1.208969 & 4.902233 & 8.733217 & 7.413307 \\ 1986 & 0.631272 & 4.902307 & 8.031580 & 7.950361 \\ 1987 & 0.631272 & 5.263364 & 7.115095 & 8.923271 \\ 1988 & 0.770108 & 5.573256 & 8.420017 & 8.561994 \\ 1989 & 1.193922 & 5.946101 & 7.600902 & 8.022115 \\ 1990 & 2.158715 & 6.158355 & 8.743822 & 8.420991 \\ 1991 & 2.239645 & 6.302014 & 9.615767 & 8.330695 \\ 1992 & 1.526056 & 6.774612 & 10.20271 & 7.348974 \\ 1993 & 3.548189 & 6.993639 & 8.968732 & 7.265157 \\ 1994 & 3.908216 & 7.244013 & 8.450342 & 9.105993 \\ 1995 & 4.092843 & 7.975001 & 12.65239 & 7.384672 \\ 1996 & 4.092843 & 8.302092 & 12.96355 & 8.132677 \\ 1997 & 4.140114 & 8.340277 & 13.51542 & 8.884915 \\ 1998 & 4.206333 & 8.291409 & 11.25948 & 8.868906 \\ 1999 & 2.510412 & 8.450955 & 13.95724 & 8.598699 \\ 2000 & 2.594508 & 8.811886 & 14.58273 & 9.146985 \\ 2001 & 3.033028 & 8.838581 & 13.90556 & 9.236744 \\ 2002 & 2.710048 & 8.961335 & 13.92287 & 8.946518 \\ 2003 & 2.445819 & 9.201655 & 13.98626 & 8.918356 \\ 2004 & 2.208274 & 9.342339 & 15.08587 & 9.738318 \\ 2005 & 2.402430 & 9.589522 & 15.39278 & 10.24988 \\ 2006 & 2.893146 & 9.829011 & 15.34869 & 10.65255 \\ 2007 & 3.089678 & 9.935825 & 14.82859 & 10.84609 \\ 2008 & 3.611998 & 10.09808 & 15.65126 & 10.87805 \\ 2009 & 2.410542 & 10.11837 & 15.65126 & 10.65449 \\ 2010 & 1.740466 & 10.90801 & 15.65126 & 10.38404 \\ 2011 & 2.410542 & 11.05058 & 16.07765 & 10.39329 \\ 2012 & 0.405465 & 11.18044 & 16.63803 & 10.68808 \\ 2013 & 2.684446 & 11.29094 & 15.79367 & 10.66546\end{array}$




$\begin{array}{lllll}2014 & 3.494991 & 11.39688 & 16.00489 & 10.44119 \\ 2015 & 4.300274 & 11.45259 & 16.34576 & 10.61298 \\ 2016 & 5.221226 & 11.11506 & 15.41276 & 10.39965 \\ 2017 & 5.221226 & 11.11506 & 15.41276 & 10.39965 \\ 2018 & 5.221226 & 11.11506 & 15.41276 & 10.39965 \\ 2019 & 5.221226 & 11.11506 & 15.41276 & 10.39965\end{array}$

\section{SOURCES: CBN STATISTICAL BULLETTIN (2016) SEE APPENDIX 1}

Where:LNFEPP $=$ Foreign Exchange parallel premium. $=($ BMER-REER $)$, $\mathrm{BMER}=$ Black Market Exchange Rate.

$\mathrm{REER}=$ Real effective exchange rate.

LNGDP $=$ Gross Domestic Product.

LNEXTRSVG= External Reserve.

$\mathrm{LNBOP}=$ Balance of Payment.BOP $=$ EXP-IMP.EXP $=$ Exportation.IMP $=$ Importation $. \mathrm{LN}=$ Acronym for $\log$ form of the variables.

\subsection{Data Analysis}

\subsubsection{Tests of Unit root using Philip and Peron}

In an attempt to confirm the order of integration of the series under study thereby confirming their suitability for a linear combination in the form of a model, the unit root test following the form specified as Philip and Peron Test was used. Table 4.3 below represents a summary of the unit root result that was stationary.

Table 4.2: SUMMARY OF UNIT ROOTS TEST RESULTS

\begin{tabular}{|c|c|c|c|c|}
\hline Variable & PP Statistic & $\begin{array}{c}\text { Critical } \\
\text { Values @ } \\
\mathbf{5 \%}\end{array}$ & $\begin{array}{c}\text { Probability } \\
\text { Value }\end{array}$ & Inference \\
\hline LNFEPP & -6.3222 & -3.5484 & 0.0000 & $\mathrm{I}(1)$ \\
\hline LNGDP & -4.5527 & -3.5485 & 0.0048 & $\mathrm{I}(1)$ \\
\hline LNBOP & -3.88576 & -3.5443 & 0.0000 & $\mathrm{I}(0)$ \\
\hline LNEXTRSV & -7.0344 & -3.5415 & 0.0000 & $1(1)$ \\
\hline
\end{tabular}

Source: Author's e-view 10 output with data in Appendix One.

From the result of Philip and Peron unit root test contained in table 4.2, Foreign Exchange Parallel Premium, Gross Domestic Product and External Reserve are all integrated of order 1(1). On the other hand, Balance of payment is integrated at 1(0) meaning that is stationary at levels. Given this different orders of integration, the Ordinary Least Square Regression Method was given up in preference for the Autoregressive Distributed Lag Model which tolerates such stationary property combination. In addition the sample size is also good enough for the ARDL given that its estimates remain robust and consistent in the face of not too large sample size and finally good for data characterized with structural brakes. Also, the variable of FEPP, GDP and EXTRSV are log transformed to bring down the data size and ensure linearity.

\subsubsection{Basic Descriptive Statistics/ Standard tests for Normality}

The statistical properties of the data sets are seen as vital determinants of their behaviors when used in econometric analyses. On the basis of this, the researcher presented in this section, the basic descriptive statistics called Normality test of the variables under study. 
Table 4.3: Basic Descriptive Statistics/ Standard tests for Normality:

$\begin{array}{lcccc} & \text { LNFEPP } & \text { LNGDP } & \text { LNBOP } & \text { LNEXTRSV } \\ \text { Mean } & 2.396255 & 8.143323 & 12.22057 & 8.966517 \\ \text { Median } & 2.428181 & 8.395588 & 13.71049 & 8.920814 \\ \text { Maximum } & 5.221220 & 11.45259 & 16.63803 & 10.87805 \\ \text { Minimum } & -0.105361 & 4.546799 & 6.780998 & 5.413430 \\ \text { Std. Dev. } & 1.361185 & 2.309027 & 3.443588 & 1.413841 \\ \text { Skewness } & -0.054803 & -0.173763 & -0.308415 & -0.370670 \\ \text { Kurtosis } & 2.183196 & 1.719840 & 1.447871 & 2.409685 \\ & & & & \\ \text { Jarque-Bera } & 1.018772 & 2.639377 & 4.184375 & 1.847084 \\ \text { Probability } & 0.000864 & 0.007219 & 0.003417 & 0.009899 \\ & & & & \\ \text { Sum } & 86.26519 & 293.1596 & 439.9407 & 322.7946 \\ \text { Sum Sq. Dev. } & 64.84886 & 186.6063 & 415.0403 & 69.96317 \\ \text { Observations } & & & & \\ \text { Source: } \text { Author's } & 36 & 36 & 36 & 36\end{array}$

Source: Author's e-view 10 output with data in Appendix One.

Table 4.3 contains the basic measures of central tendency, spread and variations calculated on the different series of the dataset. The mean of the distribution measures aggregating tendency of the data. Hence, the mean of LNFEPP is 2.7 While that of LNGDP, LNEXTRSV and LNBOP ARE 8.8, 9.2 and 12.22. The median measures the spread of the variable in the distribution .Hence, the Median of FEPP is 2.6 While that of LNGDP, LNEXTRSV and LNBOP ARE 9,9 and 14 respectively. The minimum of the distribution measures variation tendency of the data. Hence, the minimum of LNFEPP is 0.4 while that of LNGDP, LNEXTRSV and LNBOP ARE 4.5, and 7 while the maximum of the distribution measures the variation. All the variables are negatively skewed to the left showing the degree of their departure to the line of symmetry. Also, the Kurtosis of the distribution is less than 3 meaning that they are leptokurtic and are not peaked. Of particular interest is the Jacque-Bera (JB) statistics which is a test for normality. It is a combined test of Skewness (S) of zero (0) and a kurtosis (K) of three (3), which are signs of a Mesokurtic distribution. In this case, however, the JB statistics shows that the variables are tending to 3 which are signs of Mesokurtic. The assumption of normality is accepted by the JB statistics, as well as the (K) and (S) figures. This, however, does not affect the goodness of the data for the estimation in this study as the kurtosis of all the variables are between 2-3 and the Skewness above 0-1 which is consistent with the properties of most financial time series. Finally, the probability of F-statistics of the variables are statistically significant. (Brooks, 2008).

\section{VALIDATION OF HYPOTHESES}

Step 1: Restatement of the hypotheses in null and alternate form.

$\mathrm{H}_{\mathrm{O}}$ :There is no causality betweenGross Domestic Product and foreign exchange parallel

Premium in Nigeria.

$\mathrm{H}_{\mathrm{I}}$ :There is causality betweenGross Domestic Product and foreign exchange parallel premium in Nigeria. 
Step II: Presentation and discussion of the results arrived at using th estimation Technique

Table 4.8: Pair wise GrangerCausality Estimation Results for Hypothesis four

Pairwise Granger Causality Tests

Date: 04/25/19 Time: 19:52

Sample: 19812019

Lags: 2

\section{Source: Author's e-view 10 output with data in Appendix One.}

From the result presented in Table 4.8 above, a hypotheses are automatically generated to determine not just the possible existence of a causal relationship amongst the variables, but also to see whether the causality is bidirectional or unidirectional. From the table above, bidirectional causality is found between Gross Domestic Product and Foreign Exchange Parallel premium. This bidirectional causality emanates from LNGDP to LNFEPP with a feedback. This is evidenced by the fact that alternate hypotheses was accepted given that the first line is significant $0.0072<0.05$ while the second is also significant $0.0015>0.05$.

\section{Step III: Statement of Decision criteria.}

Decision Rule: Accept $\mathrm{H}_{1}$ if the probability of the F-Statistics is $<0.05$ meaning significant and reject $\mathrm{H}_{0}$ Vice versa.

Step IV: Taking a decision on the rejection or acceptance of the null or alternate hypothesis.

Hence, there is a cause and that cause results to an effect which has a feedback thereby showing that $\mathrm{H}_{\mathrm{o}}$ is rejected and $\mathrm{H}_{1}$ accepted showing that Foreign exchange parallel premium have a causal relationship with Gross Domestic Product in Nigeria and the causal relationship has a feedback from the Gross Domestic Product. Hence bidirectional causality was found between Gross Domestic Product and Foreign Exchange Parallel premium. This bidirectional causality emanates from LNGDP to LNFEPP with a feedback.

\section{Test of Hypotheses two}

\section{Step 1: Restatement of the hypotheses in null and alternate form.}

$\mathrm{H}_{\mathrm{O}}$ :There is no causality between balance of payment and foreign exchange parallel

Premium in Nigeria.

$\mathrm{H}_{\mathrm{I}}$ :There is causality between balance of payment and foreign exchange parallel premium in Nigeria. 
Step II: Presentation and discussion of the results arrived at using estimation Technique

Table 4.9: Pair wise GrangerCausality Estimation Results for Hypothesis five

Pairwise Granger Causality Tests

Date: 04/25/19 Time: 19:53

Sample: 19812019

Lags: 2

Source: Author's e-view 10 output with data in Appendix One.

From the result presented in Table 4.8 above, a hypotheses are automatically generated to determine not just the possible existence of a causal relationship amongst the variables, but also to see whether the causality is bidirectional or unidirectional. From the table above, unidirectional causality is found between balance of payment and Foreign Exchange Parallel premium. This unidirectional causality emanates from LNBOP to LNFEPP without a feedback. This is evidenced by the fact that alternate hypotheses was accepted given that the first line is significant $0.0170<0.05$ while the second is non significant $0.2108<0.05$.

\section{Step III: Statement of Decision criteria.}

Decision Rule: Accept $\mathrm{H}_{1}$ if the probability of the F-Statistics is < 0.05 meaning significant and reject $\mathrm{H}_{0}$ Vice versa.

\section{Step IV: Taking a decision on the rejection or acceptance of the null or alternate hypothesis.}

Hence, there is a cause and that cause did not results to an effect which shows that there is no feedback thereby showing that $\mathrm{H}_{\mathrm{o}}$ is rejected and $\mathrm{H}_{1}$ accepted showing that Foreign exchange parallel premium have a causal relationship with balance of payment in Nigeria and the causal relationship did not have a feedback from the balance of payment. Hence the unidirectional causality was found between balance of payment and Foreign Exchange Parallel premium. This unidirectional causality emanates from LNBOP to LNFEPP without a feedback.

\section{Test of Hypotheses three}

Step 1: Restatement of the hypotheses in null and alternate form.

$\mathrm{H}_{\mathrm{O}}$ :There is no causality between external reserve and foreign exchange parallel Premium in Nigeria.

$\mathrm{H}_{\mathrm{I}}$ :There is causality between external reserve and foreign exchange parallel premium in Nigeria. 
Step II: Presentation and discussion of the results arrived at using estimation Technique

Table 4.10: Pair wise GrangerCausality Estimation Results for Hypothesis six

Pairwise Granger Causality Tests

Date: 04/25/19 Time: 19:54

Sample: 19812019

Lags: 2

Null Hypothesis:

Obs

F-Statistic

Prob.

LNEXTRSV does not Granger Cause LNFEPP

34

0.31677

0.7310

LNFEPP does not Granger Cause LNEXTRSV

3.29653

0.0356

\section{Source: Author's e-view 10 output with data in Appendix One.}

From the result presented in Table 4.10 above, a hypotheses are automatically generated to determine not just the possible existence of a causal relationship amongst the variables, but also to see whether the causality is bidirectional or unidirectional. From the table above, unidirectional causality is found between external reserve and Foreign Exchange Parallel premium. This unidirectional causality emanates from LNFEPP to LNEXTRSV without a feedback. This is evidenced by the fact that alternate hypotheses was accepted given that the first line is significant $0.0356<0.05$ while the second is non significant $0.7310<0.05$.

\section{Step III: Statement of Decision criteria.}

Decision Rule: Accept $\mathrm{H}_{1}$ if the probability of the F-Statistics is < 0.05 meaning significant and reject $\mathrm{H}_{0}$ Vice versa.

\section{Step IV: Taking a decision on the rejection or acceptance of the null or alternate hypothesis.}

Hence, there is a cause and that cause did not results to an effect which shows that there is no feedback thereby showing that $\mathrm{H}_{\mathrm{o}}$ is rejected and $\mathrm{H}_{1}$ accepted showing that Foreign exchange parallel premium have a causal relationship with external reserve in Nigeria and the causal relationship did not have a feedback from the Foreign exchange parallel premium. Hence the unidirectional causality was found between external reserve and Foreign Exchange Parallel premium. This unidirectional causality emanates from LNFEPP to LNEXTRSV without a feedback.

\section{Findings}

The following are the specific Findings of this study:

1) Bi-directional causality existed between Gross Domestic Product and foreign Exchange parallel premium in Nigeria.

2) Uni-directional causality existed betweenbalance of paymentand foreign Exchange parallel premium in Nigeria.

3) Uni-directional causality existed between external reserve and foreign Exchange parallel premium 
Conclusion and recommendation

This study investigated the responsiveness of Foreign exchange Parallel Premium to selected Macroeconomic aggregates of Nigeria between the periods 1981 to 2017. The economic motivation of the study is anchored on the desire to find out the extent to which Foreign exchange Parallel Premium responds to Macroeconomic aggregates of Nigeria between the periods 1981 to 2018. A review of Conceptual, empirical and theoretical basis for the work was done. The research methodology concentrated on the use of the base line ARDL and granger causality estimates of cause and effect of the variables under study.

The analysis of the granger causality test reveals a bidirectional relationship existing between Foreign exchange Parallel Premium and Gross Domestic Product in Nigeria between the periods 1981 to 2018, a unidirectional causality existing between foreign exchange Parallel Premium and Balance of paymentin Nigeria between the periods 1981 to 2018, and a unidirectional causalityexisting between Foreign exchange Parallel Premium and external reservein Nigeria between the periods 1981 to 2018,

Based on findings, the study concludes that foreign exchange Parallel Premium plays a serious negative influences the Macroeconomic aggregates in Nigeria. It was also to be noted that this study can be employed for the purposes of generalization and can be expanded to capture other sphere of the economy with distinctive peculiarities. When these generalizations are made, it is capable of positioning our economy to a greater performance.

In line with the specific objectives of this study, we recommend as follows:

1) Bi-directional causality existed between foreign Exchange parallel premium and Gross Domestic Product in Nigeria.The drive for self-subsistence and sustenance by successive Nigerian government can further be enhanced by taking advantage of the interplay of Variables since there is bidirectional relationship. More effort should be done to maintain the cause and effect relationship so as to improve economic growth in both the short and long run.

2) Uni-directional causality existed between foreign Exchange parallel premium and balance of payment in Nigeria.The drive for self-subsistence and sustenance by successive Nigerian government can further be enhanced by taking advantage of the interplay of Variables since there is unidirectional relationship. More effort should be done to maintain the cause and effect relationship so as to improve balance of payment in both the short and long run.

3) Uni-directional causality existed between foreign Exchange parallel premium and Gross Domestic Product in Nigeria.The drive for self-subsistence and sustenance by successive Nigerian government can further be enhanced by taking advantage of the interplay of Variables since there is bidirectional relationship. More effort should be done to maintain the cause and effect relationship so as to improve economic growth in both the short and long run.

\section{REFERENCES}

1. Abakah, E. J. A. \&Abakah, M. K. (2016). Impact of foreign exchange reserve on stock market Growth: Evidence from Ghana. Journal of finance and economics, 4(5), 136-141.

2. Abounoori, E \& Zobeiri, H. (2010).Impact of foreign exchange parallel premium to economic Growth in Iran. International review of business research Paper, Book review 77.

3. Adeyemi, G.\& Olawoye, A. J. (2014) Impact of exchange rate on economic growth in Nigeria Australian journal of business and management research. 4(7): 9- 19

4. Adelowokan,O.J.(2012) Impact of variability of exchange rate to economic growth in Nigeria. International journal of economic development, research and investment 4(1) 
5. Amadeo, K. (2017) Effect of Export and Import on the Economy. Economic brief. USA.

6. Attah-obeng,P,E.P.Osei-Gyumah \& Opaku, C.D (2013). An Econometrics Analysis of the Relationship between GDP Growth rate and Exchange rate in Ghana. Journal of Economics and sustainable development 4(9) 1-8.

7. Ayodeji, O. \& Saheed, E. (2012).Impact of Exchange Rate on Economic Growth in Nigeria. International journal of Arts and Humanities. 2,45-53.

8. Ayodele, O.\& Obafemi, F.N.(2015). Fiscal and Quasi effect of the Foreign exchange parallel premium to Economic Growth in Nigeria. AERC, Niraobi, Kenya.

9. Dada,A.E.\&Oyerenti, O.A. (2012). Links between Exchange Rate and Macro Economic Variables in Nigeria. Journal of Economics and Sustainable Development 3(2) 91 - 101.

10. Degafa,D.(2001). Determinant of Foreign Exchange Parallel Premium to Macro Economic Performance in Ethiopia. AERC Research 107.

11. Dorduno, C. K (1994). The Foreign Exchange market and the Dutch action system in Ghana. AERC Research paper 24.

12. Dornbusch,R.(1989).Open Macroeconomic. $2^{\text {nd }}$ Edition, London. New York Publication.

13. Ebaidella, E.M. (2017). Impact of Foreign exchange Parallel premium to Macro Economic Performance in Sudan. A paper prepared for ERF $23^{\text {rd }}$ Annual conference, Ammar, Jordan march 2017.

14. Ebaidalla, E. \& Abidalla, E. (2014). Impact of Foreign exchange Parallel premium to Macro Economic Performance and Flow of Migrant Remittance in Sudan.. Middle East Development Journal 7(1), 70 - 88.)

15. Hung, B.D (2015) Impact of Foreign Exchange parallel premium to the Economy. An Empirical Analysis of Vietnam. Journal of Griffith Business School, Queen and Australia 23(3) 302-310.

16. Ibrahim,W. (2011).Impact of Changes in External reserve holdings in Nigeria to Domestic investment, inflation and exchange rate. Journal of Economics and International Finance, 2(9), 183-192.

17. Imosi, A.I Uzomba, P.C. \& Olatunji, L.M (2010)Effect of Interest Rate and Exchange Rate effect on the Nigerian Economy .Asian Economic and Financial Review 2(6) 575 584.

18. Ismaila,A.M.(2016).long run impact of Exchange Rate Depreciation to Nigerian Economic Performance after Structural Adjustment Era. NG Journal of Social Development 5(2).

19. Jhingan ,M. L. (2010) .Macro Economic Theory. $12^{\text {th }}$ Edition and Enlarged edition Vrinda Publication Ltd, New Delhi. India.

20. Kiguel,N. \& O'Connel, S. A (1995).Effect of Foreign exchange Parallel premium on Exchange Rate and GDP Tanzania .Policy Research Working Paper WPS 1265.

21. Makochekenwa, A. (2010). Impact of Foreign Exchange parallel premium to Economic Growth in Zimbabwe. Email. Almac772002@yahoo.com Affiliated to the Department of Economics, University of Pretoria South Africa.

22. Mohammed, S. (2008). Financial -Growth Nexus in Sudan. Empirical Assessment based on an autoregressive Distributed Lag Model. (ARDI). Arab Planning Institute, Working Paper Series.

23. Ngerebo-a, T. A.\& Ibe, R. C.(2013).Causal Relationship existing Exchange rate and macroeconomic performance in Nigeria: A post structural adjustment programme investigation. Global Journal of Management and Business Research Finance, 13(7), 4348.

24. Nkuranziza, J.D. (2002). Impact Foreign Exchange Parallel Premium to Macro Economic Performance in Burundi. AERC Research paper 123. 
25. Odazi,V.A.(2015).Government Policies in Relation to Foreign Exchange Management. Being an Address Presented at the $2^{\text {nd }}$ lecture of the Nigeria British Chamber of Commerce on $14^{\text {th }}$ June 2015 at the Federal Palace hotal, Victoria Island Lagos.

26. Odogun, P. J. (1995) .Foreign Exchange Management in Nigeria .CBN Economic and Financial Review 31 (4).

27. Odusola,A.F.\& Akinlo,A.E.(2012).Impact of Inflation and Exchange Rate to Output in Developing Countries. An Application to Nigeria.The Developmental Economic 39(2) 199-222.

28. Okeafor, (2014) .Parallel Premium, An Indirect creation by Monetary Authorities to enhance flexibility. Journal of management sciences, Ambrose Alli University, Ekpoma Edo State, Nigeria.

29. Olayungbo, D. O. \&Akinbobola, T. O.(2011). Relationship between Foreign exchange reserves and exchange rates in Nigeria. Journal of Social and Economic Development,1(1), 1-6.

30. Oleka, D.C (2009). Development Finance; Money and Capital Market, Financial Management and Investment. Enugu. HipUKS Additional press Co.

31. Onwumere, J.U.J (2009) .Business and Economic Research Method. Vougasen Ltd, Enugu. $2^{\text {nd }}$ Edition

32. Orji, J. (2001). Seminar in Finance.Splash Media Publication Enugu.

33. Pinto, B C (1988) Impact of Black Market Foreign Exchange rate on REER and Inflation in Sub sahara Africa. World Bank Economic Review 3, 32.Pr

34. Shobande,O.A \& Odeleye, A.T. (2015).Effect of Exchange Rate Policy on Economy. A case of Nigeria. Development Country studies 5 (13).

35. Umoru, D. \&Odjegba, O. P. (2013).Relationship between Exchange rate misalignment and balance of payment adjustment in Nigeria. European Scientific Journal, 9(13), 260273.

36. Usman,O. A.(2004).Impact of Foreign Exchange Rate fluctuation to Industrial Produce in Nigeria. Global advanced Journal of Economies, Accounting and finance 1.1-8.

37. Yh-Hsing A.(2006).Determinant of Exchange Rate and its Implication in Venezueian Economy..International Journal of Humanities and Social Sciences. 2 (13).

\begin{tabular}{rrrrrrrrr}
\multicolumn{7}{c}{ APPENDIX 1 } \\
YEAR & PMER & REER & FEPP & \multicolumn{1}{c}{ GDP } & EXTRSV & \multicolumn{1}{l}{ IMP } & \multicolumn{1}{c}{ EXP } & \multicolumn{1}{c}{ BOP } \\
1981 & 1.51 & 0.61 & 0.9 & 94.33 & 2441.6 & 12599.1 & 11011.08 & -1588.02 \\
1982 & 1.69 & 0.67 & 1.02 & 101.01 & 1043.3 & 10096.1 & 9196.36 & -899.74 \\
1983 & 2.51 & 0.72 & 1.79 & 110.06 & 224.4 & 6551.85 & 7749.36 & 1197.51 \\
1984 & 4.26 & 0.76 & 3.5 & 116.27 & 710.1 & 4481.05 & 9137.77 & 4656.72 \\
1985 & 4.24 & 0.89 & 3.35 & 134.59 & 1657.9 & 5533.03 & 11738.69 & 6205.66 \\
1986 & 3.9 & 2.02 & 1.88 & 134.6 & 2836.6 & 5970.86 & 9047.46 & 3076.6 \\
1987 & 5.9 & 4.02 & 1.88 & 193.13 & 7504.6 & 15645.3 & 16875.7 & 1230.4 \\
1988 & 6.7 & 4.54 & 2.16 & 263.29 & 5229.1 & 17642.62 & 22179.6 & 4536.98 \\
1989 & 10.7 & 7.4 & 3.3 & 382.26 & 3047.6 & 23179.17 & 25179.17 & 2000 \\
1990 & 16.7 & 8.04 & 8.66 & 472.65 & 4541.4 & 34704.68 & 40976.5 & 6271.82 \\
1991 & 19.3 & 9.91 & 9.39 & 545.67 & 4149.3 & 69981.88 & 84981.3 & 14999.42 \\
1992 & 21.9 & 17.3 & 4.6 & 875.34 & 1554.6 & 152901.6 & 179877.6 & 26976.1 \\
1993 & 56.8 & 22.05 & 34.75 & 1089.68 & 1429.6 & 181924.1 & 189777.7 & 7853.64 \\
1994 & 71.7 & 21.89 & 49.81 & 1399.7 & 9009.1 & 98747.85 & 103424.5 & 4676.67 \\
1995 & 81.8 & 21.89 & 59.91 & 2907.36 & 1611.1 & 254701.6 & 567211 & 312509.4 \\
1996 & 81.8 & 21.89 & 59.91 & 4032.3 & 3403.9 & 375194 & 801752.1 & 426558.1 \\
\hline
\end{tabular}


https://dx.doi.org/10.26808/rs.rmf.v4i4.02

International Journal of Research in Management Fields Available online on http://rspublication.com/IJRMF/IJRMF.html

ISSN (P) 2577-1876 (O) 2577-4274

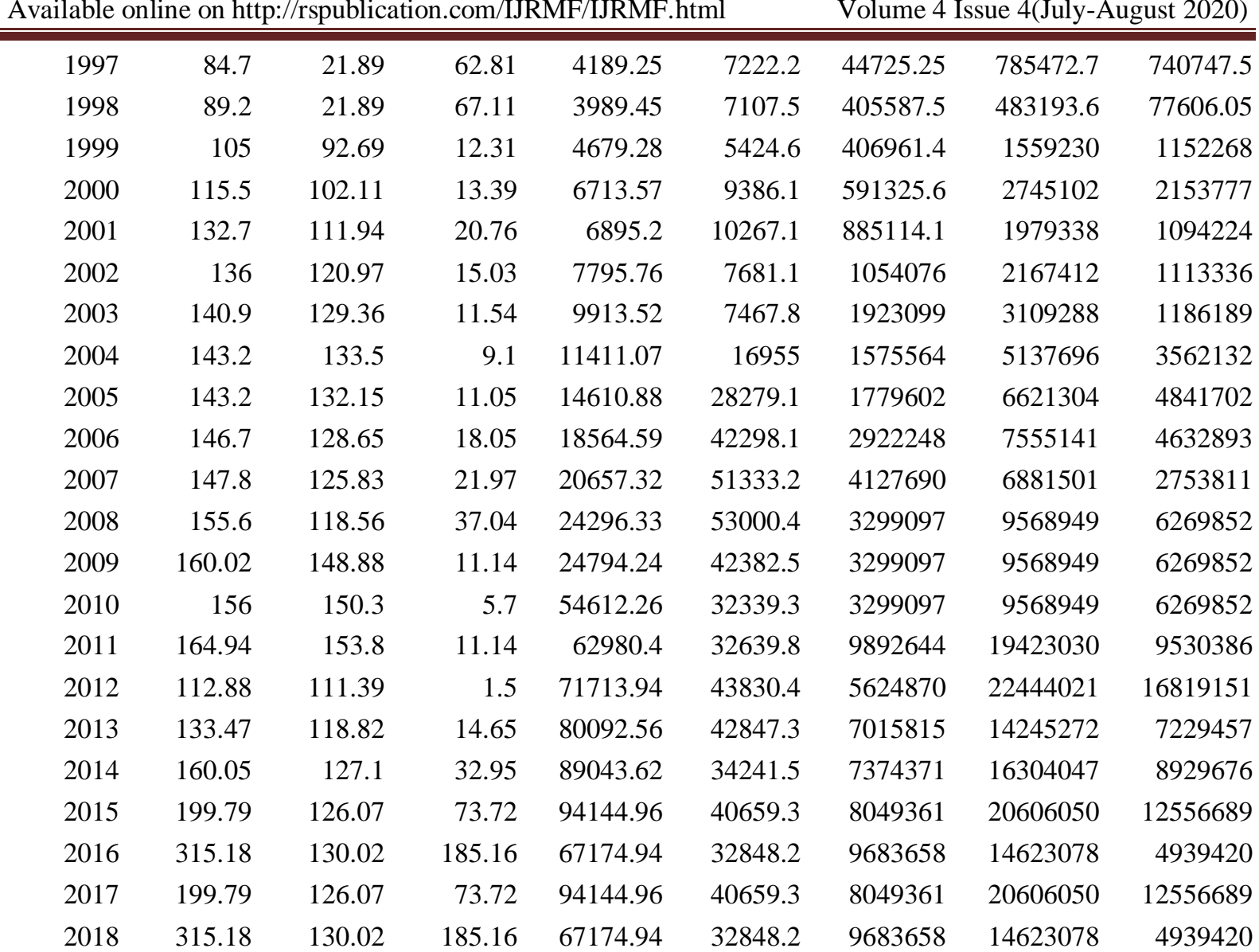

SOURCES: CBN STATISTICAL BULLETTIN (2018) 